\title{
Contributors
}

Carlos A. Arcila holds a Masters in Ethnomusicology at Your University, in Toronto, Canada, in 2012; a Masters in orchestra conductor at Juan N. Corpas University in Bogotá, Colombia, in 2004; and a degree in flute performance at the Conservatoire of Antonio María Valencia in Cali, Colombia, in 1999. His research focuses on oral tradition music from the South West Pacific Coast in Colombia. He started his research about this music in 1999. In 2001, Carlos won a National Award of Music Composition with the work "Homage to Left-Handed Julian Symphonic Band and Pacific Colombian Folk Group", to honor his recently dead friend that introduced him to the rich and beautiful oral tradition music of the Colombian Pacific coast. During his masters in orchestra conductor (2003-2004), he continued his research and collected data from the field. His master's thesis in Colombia "El Currulao" included a CD-ROOM. Then, Carlos MA Ethnomusicology thesis at York University involved the work presented in this webpage: "A Multimedia Stylistic Analysis of the Marimba de Chonta Performance Practice in Guapi, Cauca".

In addition to research and composition, Carlos has a large trajectory as flute performer, teacher, as well as symphonic orchestra and wind band conductor. During 20 years, he played with the Symphonic Band of the Banda Departmental del Valle in Cali, Colombia and performed numerous sessions with the Symphonic Orchestra of Valle in Cali, Colombia. Besides, Carlos performed Latin Jazz music and other traditional music genres with different ensembles. He was conductor of the Symphonic Band and teacher at Juan N. Corpas University, in Bogotá, Colombia.

Carlos has been interested in sound arts during his long career as a musician. In Colombia, he developed his skills in music post-production working in several recording companies and later on in his own private audio-postproduction studio. In 2010, he obtained a Graduate Diploma in Audio Post-Production in Fanshawe College in London, Canada and has continued working as audio-postproduction specialist. Acquiring these skills has provided him with resourceful tools in his journey as researcher.

The links below provide some samples of Carlos A. Arcila's works:

http://marimbadechonta.com/

http://arcilac.blogspot.ca/

http://musicforgame.blogspot.ca/

At present, Sonia Aujla-Bhullar is a PhD student, and the recipient of an Eyes High Doctoral Scholarship, Werklund School of Education, University of Calgary. Her current doctoral research concentrates on issues of leadership and inclusive practice in schools with a very diverse ethnic/racial and cultural demographic. Ms. Aujla-Bhullar was born and raised in Calgary. As a public school teacher, Aujla-Bhullar has worked with an increasingly more diverse and a growing population, comprised of students, teachers, and families, (both within and outside the school community). She has dedicated much of her life to work and voluntary activities in the field of diversity. As a volunteer, she has worked with mainstream organizations such as: the South Asian Police Advisory Committee (SAPAC); the Calgary Police Service; and has been an active Board Member of the Alberta Association of Multicultural Education in educational planning and advocacy in and around community engagement.

Cultural and Pedagogical Inquiry, 2016, 8(2), pp. 85-89

ISSN 1916-3460 @ 2015 University of Alberta

http://ejournals.library.ualberta.ca/index.php/cpi/index 
Originally from Jamaica, Yvonne Brown has completed doctoral and master's studies at The University of British Columbia (UBC). Having lived in Vancouver and British Columbia for most of her adult life, Dr. Brown has had a distinguished professional career as an educator in public schools and at the University. In this capacity, she has made significant contributions to the field, for example, as a public school teacher, university lecturer, policy analyst, manager of international initiatives, and school trustee. Her research interests include: critical perspectives on multicultural education, social justice issues, northsouth development education, and internationalization of higher education. At present, Dr. Brown lives in Toronto. In retirement, she has reinvented herself as a creative non-fiction researcher and writer; has published a book and is actively, conducting archival research in Jamaica and England for her second book. A few years ago she was the research fellow at the Harriet Tubman Institute, York University, Ontario, Canada.

Hilary R. Burke worked in five countries before coming to Canada in November 1982. Since then, she has listened to a great many accounts from immigrants who have struggled to earn a basic living in Canada for decades even after they obtained Canadian credentials (often degrees at the post-graduate level \& or diplomas in technology), in addition to the credentials they had when they arrived. After Semper (not his real name) related his story to her, she started writing this docu-play, which has taken over twelve years to complete. This work is her tribute to the enduring spirit of optimism, which underlies the feelings of those mired in disillusionment or entrapment \& others affected by them.

Born in Jamaica, Carol Campbell graduated in 1974 from the Alberta College of Art, (now The Alberta College of Art and Design), Canada, with a Diploma in Applied Art, (Jewellery and Metals major, Fabrics minor).

She has distinguished herself in the field of Jewellery Design, internationally winning awards for her innovative use of surface and colour in her one-of-a-kind signature pieces. In recent years, her work has been breaking new ground, successfully combining sculpture and installation elements with wearable Jewellery.

Her talents have been engaged in the Jewellery, Fashion, and Film industries, as well as in Education, Museums, and the Performing Arts. She has acted as consultant to many Art/Craft organizations in Jamaica, the Caribbean, and North America, including The Jamaica Guild of Artists, UNESCO, Jamaica; Caribbean Export Development Agency (CEDA) (Barbados); Diasporavibe Cultural Incubator (Miami); The Clive Thompson Foundation for Dance Education; The Alberta Craft Council, (Vice President, 1990 - 1995), and the Oak Bark Foundation (Founding member) both in Canada).

\section{Teaching Experience:}

1999 - Present - Edna Manley College for the Visual and Performing Arts, Kingston Jamaica 1979 - 1989 - Alberta College of Art, Calgary, Alberta, Canada

\section{Participation:}

(In association with Diasporavibe Gallery, Miami):

- 2012 - International Cultural Exchange, Barbados

- 2010 - International Cultural Exchange, St. Maarten

- $\quad 2009$ \& 2013 - International Cultural Exchange, Jamaica

- 2008 - International Cultural Exchange, Puerto Rico

- 2006 - International Cultural Exchange, Nassau Bahamas

- 2001 - 2011. Owner/Curator for Revolution Gallery (for exceptional craft objects) in Kingston, Jamaica

Cultural and Pedagogical Inquiry, 2016, 8(2), pp. 85-89

ISSN 1916-3460 @ 2015 University of Alberta

http://ejournals.library.ualberta.ca/index.php/cpi/index 
- 1988 - 1996 - Owner/Designer Goldsmith for Carol Campbell Design, Calgary, Alberta, Canada

- 2011, 2013, 2015 - Presenter/Exhibitor, Rex Nettleford International Arts Conference, Edna Manley College of the Visual \& Performing Arts, Kingston, Jamaica

\section{Major commissions include:}

- The design and production of a brooch for Her Majesty Queen Elizabeth, the Queen Mother, in honour of her $100^{\text {th }}$ birthday, as a gift from Jamaica;

- The design and production of the prestigious Aaron Matalon Biennial Awards for the National Gallery of Jamaica since 2002;

- Episcopal rings and other gifts for the Diocese of Jamaica.

\section{Local awards:}

- 2014, she was awarded Third Prize for Jewellery entered in the Industrial Materials Category of the inaugural Authentic Jamaica Design Competition.

- 2012 was a finalist (Honourable Mention) in the UNESCO Award for Excellence in Craft in the English Speaking Caribbean.

- 2011- was one of twelve (12) craft artists chosen to exhibit in the inaugural Design Caribbean exposition in Santo Domingo;

- 2009 - EU Upgrading Grant through PSDP

- 2005, 2007 silver medals for her entries in the Jamaica Cultural Development Commission National Fine Art Competition.

\section{International Awards:}

- 1996 - Alberta Foundation for the Arts Research Grant - "Cultural Influences on Design of the Applied Arts in Jamaica"

- $\quad 1987$ - Canadian Jeweller Magazine, Editor's Choice for Fine Jewellery, and Fashion Jewellery

Ms. Campbell has been a senior lecturer in the Jewellery Department at The Edna Manley College of the Visual and Performing Arts, for 15 years. She also maintains a private studio practice, where she mentors selected graduates from the Jewellery Department. She is a member of the American Craft Council, the Society of North American Goldsmiths, and the Visual Arts Jamaica cluster.

Born in Zimbabwe, Charles Chikunda did his $\mathrm{PhD}$ with Rhodes University and master's studies with university of Zimbabwe. Having worked in Zimbabwe, Namibia and South Africa, Charles has had a notable professional career for more than 20 years as a science teacher and teacher educator with main focus on Science Education and Education for Sustainable Development. He has published numerous journal articles and book chapters in these fields. At present Charles is working for a development organisation as a senior researcher in South Africa.

Plaxcedes Chikunda is a lecturer of Sociology of Education at the Great Zimbabwe University. Plaxcedes has had a noteworthy professional career going beyond 20 years, as an educator in public schools and at tertiary level in various institutions in Zimbabwe. In this capacity, she has made significant contributions as a school teacher, head of department, examiner and university lecturer. Her research interests include: critical perspectives on deviance in education, equality and social justice issues in education. 
Highly respected for his continuing, literary contributions to Canada, Cyril Dabydeen's recent books include: God's Spider/poetry (Peepal Tree Press, UK), My Multi-Ethnic Friends and Other Stories (Guernica Editions, Toronto), and the anthology Beyond Sangre Grande: Caribbean Writing Today (Tsar/Mawenzi House, Toronto).

Previously, Dabydeen is noted for books such as: Jogging in Havana (1992), Black Jesus and Other Stories (1996), Berbice Crossing (1997), My Brahmin Days (2000), North of the Equator (2001), Play a Song Somebody: New and Selected Short Stories (2003), Imaginary Origins: New and Selected Poems (2005), and the novel, Drums of My Flesh (2007)--winner of the International Guyana Prize for best novel.

Cyril Dabydeen's work has appeared in over 60 literary magazines and anthologies world-wide. In 2016, he was invited to England to present some of his work. In 2015, he was invited to present at the Canadian Social Sciences and Humanities Congress, University of Ottawa. A former Poet Laureate of Ottawa (1984-87), Dabydeen well known for his tireless work in social justice issues with federal and municipal governments. (For a decade, he managed, for example, the Federation of Canadian Municipalities Race Relations Program). At present, he teaches Creative Writing at the University of Ottawa.

A former Commonwealth Scholar, Cecille DePass, PhD, Education, University of Calgary), MA, BA (Economic Geography, Victoria University of Wellington, New Zealand), Post graduate Diploma in Education, BA, (University of the West Indies, UWI), has recently become a University of Calgary, Professor Emerita (June 2015), and the recipient, of the Comparative and International Education Society of Canada (CIESC), David Wilson Award (June 2015) for lifetime services to CIESC and to the field. From its inception, DePass has been a founder and co-editor with Ali A. Abdi (currently, Head, Department of Educational Studies, Faculty of Education, UBC), of the independent journal, Cultural and Pedagogical Inquiry.

At present, she has initiated two pilot international, development education, research projects in Jamaica, one of which is affiliated with the UWI. Both projects have potential for tremendous growth which she will actively foster. Dr. DePass has been involved in the interdisciplinary field of Comparative and International Education since the late 1980s. She has published a large number of conference presentations, articles and book chapters, all of which explore implicitly and explicitly, issues of multiculturalism, equity, and life chances of immigrants and their families. Cecille DePass is perhaps, best known for the spirited approach, concern for social justice issues, and infusion of the arts in her teaching, research, conference presentations and writing.

Calgary-based artist Kim Huynh immigrated to Vancouver from Vietnam in 1980. She studied art theory, philosophy before going on to receive a Bachelor of Fine Arts from the University of Victoria in 1990 and a Master of Fine Arts from the University of Alberta in 1992. Huynh is an associate professor in the Department of Art, University of Calgary since 1999. Over the last 15 years, Huynh's research has focused on shifting Chinese-Canadian multiculturalism, hybrid identity, and the transformations created by the impact of globalization. 
Carol Lee is a PhD student in the Faculty of Education at the University of Ottawa where she is researching child authorship. She edited The Missing Bone (2001) a child authored novel that sold in a major book store Canada wide. Prior to her PhD studies, Carol was a consulting writer for 20 years in the Ottawa business and high technology sector. Carol is also an active creative writer in the Ottawa poetry community and has just finished a collection of refugee poems titled No Return.

On campus, Carol is a member of the organizing committee for the Jean Paul Dionne Symposium, an annual conference for graduate students in Education, which has as one of its theme's this year, social justice in and through education. Carol's current efforts on issues of social justice are focused primarily on changing Canada's origin story from the "Confederation" story to one that recognizes First Nations as founding peoples of Canada together with the French and English. She has given papers at various conferences from 1992 to present, the most recent being, Song Comes First (2016). JPDS uOttawa, Writing Circles, Readings, Chap Books: A Community of Practice (2016) Artful Inquiry Symposium, McGill University, and Taking the "con" out of Confederation (2017) Provoking Curriculum, McGill University (proposed).

Ziya Lin completed her B.F.A. Program at Sichuan Fine Art Institute (Chongqing, China), concentrated in Chinese painting, in 2014. And she started her graduate studies at University of Calgary since 2015, engaging in the drawing and installation. Ziya's artistic practice and research focus on visualizing the constraints in her personal as well as collective lived experiences. As she lives in a society that people's personalities, lifestyles, identities, behaviors and even the ways of thinking are shaped by social norms or influenced by the will of others, through her work, Ziya hopes to evoke people's attention and concerns on their mental state under restraints.

Originally from Karachi, Pakistan, Maria Wallis arrived in Ontario, Canada, as a teenager with her family. She has a BA from McGill, a Masters from McMaster, an additional Masters of Social Work, and a doctorate from York University. She was involved in community organizing for over 15 years in Toronto. Dr. Wallis has co-edited three academic books on Race/Racism in Canada. She has been an Adjunct faculty at several universities and held a tenure-track, faculty position at the University of Western Ontario. At present, after experiences that will be documented, she is an Adjunct faculty in the Department of Equity Studies at York University. She is currently working on research and a book on community and individual resistances to systemic, racial exclusionary practices in Canada. She is also mother to thirteen-year-old Rose Wallis who continues to inspire her to create a racially just society in Canada.

Rita Wong has published four books of poetry while living on the unceded Coast Salish territories, also known as, Vancouver. The books are: monkeypuzzle (Press Gang, 1998), forage (Nightwood Editions, 2007), sybil unrest (Line Books, 2008, with Larissa Lai) and undercurrent (Nightwood, 2015). As importantly, she has produced a series of graphic essays entitled, "perpetual" (with Cindy Mochizuki, Nightwood 2015). The book of poetry, "forage" won the 2008 Dorothy Livesay Poetry Prize and Canada Reads Poetry in 2011. Rita Wong's work focuses, predominantly, on learning from and with water as a path to decolonize and to nourish social justice. 